$\mathrm{R}$ osidah U mami 0 ctavia

U paya Melatih Kemandirian Belajar M elalui Lear ning (ODL) Siswa Kelas

III SDN Pucang 4 Siddarijo

\title{
UPAYA MELATIH KEMANDIRIAN BELAJAR MELALUI OUTDOOR LEARNING (ODL) SISWA KELAS III SDN PUCANG 4 SIDOARJO
}

\author{
Rosyidah Umami Octavia \\ STKIP PGRI SIDOARJO \\ rosyidahumami2510@gmail.com
}

\begin{abstract}
Abstrak
Dalam melakukan interkasi selama proses pembelajaran di kelas sebagian besar siswa kurang mandiri. Penelitian ini berupaya untuk melatih kemandirian belajar siswa melalui outdoor learning. Penelitian ini menggunakan pendekatan kualitatif, yaitu penelitian yang menghasilkan data deskriptif berupa kata-kata tertulis dan lisan dari orang-orang dan perilaku yang dapat diamati. Jenis penelitian ini adalah penelitian deskriptif, yakni peneliti menyelidiki keadaan, kondisi, situasi, peristiwa, dan kegiatan, yang hasilnya dipaparkan dalam bentuk laporan penelitian. Sedangkan jenis penelitian yang digunakan adalah deskriptif yaitu dengan memaparkan gambaran dan penjelasan secara sistematis mengenai data-data yang diperoleh dalam penelitian dan fenomena yang diselidiki berdasarkan rumusan masalah.

Berdasarkan hasil observasi belajar siswa nilai rata-rata aktifitas peserta didik pada pertemuan pertama adalah 2,967, pertemuan kedua adalah 3,562, dan pertemuan yang terakhir adalah 3,931. Kesimpulan penelitian ini menunjukkan bahwa siswa kelas III SD Negeri Pucang 4 Sidoarjo sangat antusias dan bersemangat, sehingga interaksi proses pembelajaran dapat berlangsung sesuai dengan yang diharapkan.

Kata Kunci: Kemandirian Belajar, Outdoor Learning

\section{Abstract}

In doing interaction during learning process in the classroom, most of the students are less independence. This research is an effort to practice independent of students' learning through outdoor learning This study uses a qualitative approach, which is research that produces descriptive data in the form of written and oral words from people and observable behavior. This type of research is a descriptive study, the researcher investigates the circumstances, conditions, situations, events, and activities, the results of which are presented in the form of research reports. While the type of research used is descriptive, namely by describing systematically the description and explanation of the data obtained in the study and the phenomena investigated based on the problem formulation.
\end{abstract}

MUBTADI: Jurnal Pendidikan Ibtidaiyah

Vol. 2 No. 1, Juli - Desember 2020

$P$ - ISSN : $2715-7067$

E - ISSN : 2720 - 8850 
Based on the result of students' learning observation, the mean value of students' activities in first meeting is 2,967 , the second meeting is 3,562, and the last meeting is 3,931. The conclusion of this research show that the third grade students of SD Negeri Pucang 4 Sidoarjo are very enthusiastic and happy in learning process. Therefore, the interaction of learning process can be done based on our hope.

\section{Keyword: The Independence of Learning, Outdoor Learning}

\section{PENDAHULUAN}

Pendidikan dasar merupakan masa perkembangan dan pertumbuhan yang sangat menentukan perkembangan masa selanjutnya. Penelitian yang dilakukan oleh pakar pendidikan menyimpulkan bahwa pendidikan anak usia sekolah dasar dapat memperbaiki prestasi dan meingkatkan produktivitas kerjanya di masa mendatang. Anak mampu mengerjakan perkerjaannya sendiri tanpa bergantung kepada orang lain dan merasakan kepuasan tersendiri dengan apa yang telah dia lakukan. Dalam meningkatkan kualitas pembelajaran di sekolah dasar banyak faktor yang harus diperhatikan. Guru dan siswa merupakan dua komponen utama, yang berperan aktif dalam berlangsungnya kegiatan pembelajaran. Belajar dengan mandiri dapat diartikan sebagai kegiatan belajar aktif yang diimbangi dengan niat untuk menguasai suatu kompetensiyang dapat digunakan untuk mengatasi suatu masalah dengan bekal ilmu pengetahuan yang telah dimiliki.

Kemandirian seseorang berhubungan dengan pribadi yang mandiri, aktif, kreatif, dan mampu untuk melakukan adaptasi dan menangani segala hal dengan sendiri. Mandiri sebuah kata yang bermakna luas. Kata ini dapat diartikan suatu kemampuan pribadi untuk menyelesaikan berbagai permasalahan diri, baik ringan atau berat. Istilah "kemandirian" berasal dari kata dasar "diri" yang mendapat awalan "ke" dan akhiran "an", kemudian membentuk satu kata keadaan atau kata benda. Karena kemandirian berasal dari kata dasar "diri", maka pembahasan mengenai kemandirian tidak bisa lepas dari pembahasan tentang perkembangan diri itu sendiri, yang ada dalam konsep Carl Rogers disebut dengan istilah self, karena diri itu merupakan inti dari kemandirian. Konsep yang sering digunakan atau berdekatan dengan kemandirian adalah autonomy, (Desmita, 2016:9).

McDougal (dalam Ali dan Asrori, 2015:45) mengatakan bahwa kemandirian merupakan konformitas khusus, yang berarti suatu konformitas terhadap kelompok yang terinternalisasi. Lebih lanjut ditegaskan bahwa setiap individu selalu berkonformitas, dan yang membedakan konformitas antara idividu satu dengan lainnya adalah variabel 
kelompok rujukan yang disukainya. Mohammad (dalam Maulani, 2013:54) kemandirian merupakan salah satu aspek kepribadian yang sangat penting bagi individu. Individu yang memiliki kemandirian tinggi relatif mampu menghadapi segala permasalahan karena tidak tergantung pada orang lain, selalu berusaha menghadapi dan memecahkan masalah yang ada.

Menurut Masrun dkk (dalam Patriana, 2007:10) kemandirian adalah suatu sikap yang memungkinkan seseorang untuk berbuat bebas, melakukan sesuatu atau dorongan diri sendiri untuk kebutuhan sendiri, mengejar prestasi, penuh ketekunan, serta berkeinginan, untuk melakukan sesuatu tanpa bantuan orang lain, mampu berpikir dan bertindak original, kreatif dan penuh inisiatif, mampu mempengaruhi lingkungannya, mempunyai rasa percaya diriterhadap kemampuan diri sendiri, menghargai keadaan diri sendiri, dan memperoleh kepuasan dari usahanya.

Faktor kemandirian belajar dapat pula dipengaruhi oleh adanya metode mengajar yang digunakan guru dalam menyampaikan materi. Metode konvensional seperti ceramah abstrak, hafalan materi pelajaran, dan mencatat di buku tulis kurang dapat melatih kemandirian siswa. Untuk menumbuhkan sikap kemandirian belajar siswa harus mampu mengoptimalkan kecerdasan membaca dan menulis, membangun lingkungan belajarnya sendiri serta mengevaluasi perkembangan siswa pada proses pembelajran (Lipton dan Hubble, 2005:15).

Berdasarkan observasi awal di kelas III SD Negeri Pucang 4 Sidoarjo pada semester ganjil tahun ajaran 2019/2020 tampak sebagian siswa sangat kurang mandiri selama proses pembelajaran berlangsung. Hal ini dibuktikan ketika mengerjakan lembar kerja siswa atau tugas individu yang diberikan guru, masih banyak siswa yang bertanya pada temannya. Sehingga selama proses pembelajaran mereka cenderung lebih pasif. Oleh sebab itu, peneliti ingin melatih kemandirian belajar siswa melalui outdoor learning untuk membuat siswa lebih aktif, kreatif, dan dapat melatih kemandiriannya dalam proses pembelajaran serta dapat mencapai ketuntasan dalam belajarnya.

\section{METODE PENELITIAN}

Pendekatan yang digunakan dalam penelitian ini adalah kualitatif. "Pendekatan kualitatif adalah prosedur penelitian yang menghasilkan data deskriptif berupa kata-kata tertulis dan lisan dari orang-orang dan perilaku yang dapat diamati" (Moleong, 2007:4). Jenis penelitian ini adalah penelitian deskriptif dimana peneliti dimaksudkan untuk menyelidiki keadaan, kondisi, situasi, peristiwa, kegiatan, yang hasilnya dipaparkan dalam bentuk laporan penelitian (Arikunto, 2010:3). Sedangkan jenis penelitian yang digunakan adalah deskriptif yaitu dengan memaparkan gambaran serta penjelasan secara sistematis 
mengenai data-data yang diperoleh dalam penelitian, sifat-sifat antara fenomena yang diselidiki berdasarkan rumusan masalah.

"Subjek penelitian adalah tempat dimana data untuk variabel penelitian diperoleh" (Arikunto, 2010:14).Penelitian ini menggunakan pendekatan kualitatif, yaitu penelitian yang menghasilkan data deskriptif berupa kata-kata tertulis dan lisan dari orang-orang dan perilaku yang dapat diamati. Jenis penelitian ini adalah penelitian deskriptif, yakni peneliti menyelidiki keadaan, kondisi, situasi, peristiwa, dan kegiatan, yang hasilnya dipaparkan dalam bentuk laporan penelitian. Sedangkan jenis penelitian yang digunakan adalah deskriptif yaitu dengan memaparkan gambaran dan penjelasan secara sistematis mengenai data-data yang diperoleh dalam penelitian dan fenomena yang diselidiki berdasarkan rumusan masalah.

Subjek dalam penelitian ini adalah siswa kelas III SD Negeri Pucang 4 Sidoarjo yang berjumlah 32 siswa yang terdiri atas 15 perempuan dan 17 laki-laki. Penelitian ini dilaksanakan pada semester ganjil tahun ajaran 2019/2020. Instrumen penelitian yang digunakan oleh peneliti berupa angket dan lembar observasi aktifitas siswa dan guru serta wawancara yang dilakukan kepada siswa dan guru untuk mengetahui respon pembelajaran melalui outdoor laerning.

Peneliti melakukan observasi untuk melihat aktifitas belajar siswa dan kemandirian belajar siswa selama proses pembelajaran berlangsung. Lembar observasi diberikan kepada guru pengamat atau observer. Sedangkan wawancara siswa dan guru digunakan untuk memperkuat hasil dari observasi yang telah dilakukan. Sedangkan angket digunakan untuk memperkuat hasil observasi siswa dan guru terhadap pembelajaran dengan menggunakan outdoor learning bagi siswa kelas III SDN Pucang 4 Sidoarjo.

\section{HASIL PENELITIAN DAN PEMBAHASAN}

Kegiatan outdoor learning dapat dimanfaatkan oleh guru untuk meningkatkan kualitas pembelajaran dan upaya melatih kemandirian belajar peserta didik. Kegiatan pembelajaran berbasis outdoor learning ini mampu membuat wawasan guru lebih berkembang dan selalu termotivasi untuk selalu berinovasi dalam mengajar yang selanjutnya akan menjadi guru yang professional.

Teknik pengumpulan data pada penelitian ini menggunakan teknik angket atau kuesioner serta menggunakan pedoman observasi. Teknik angket merupakan pengumpulan data yang dilakukan dengan cara memberi seperangkat pertanyaan atau pernyataan tertulis kepada responden untuk menjawabnya. Pengumpulan data dilakukan pada sumber data yaitu siswa dan guru kelas. Indikator-indikator tersebut sebagai acuan pelaksanaan penelitian evaluasi pelaksanaan outdoor learning di kelas III SDN Pucang 4 Sidoarjo. 
Berdasarkan hasil observasi aktifitas belajar siswa pada pertemuan pertama nilai rata-ratanya sebesar 2,967, pertemuan kedua sebesar 3,562 dan pertemuan ketiga diperoleh hasil 3,931. Selain untuk mengetahui aktifitas belajar siswa, peneliti juga menganalisis ketuntasan hasil belajar siswa.

Hasil ini menunjukkan bahwa upaya melatih kemandirian belajar siswa melalui outdoor learning berdampak positif dan dapat meningkatkan aktifitas belajar siswa. Upaya melatih kemandirian belajar siswa melalui outdoor learning yang diterapkan pada kelas III SD Negeri Pucang 4 Sidoarjo juga mendapat respon positif dari guru yang menjadi observer. Hasil wawancara dengan siswa menunjukkan bahwa siswa menyambut posistif adanya upaya melatih kemandirian belajar siswa melalui outdoor learning. Dalam hal ini siswa sangat antusias dan senang mengikuti pembelajaran dengan menerapkan outdoor learning. Sedangkan hasil wawancara dengan guru juga menunjukkan respon positif yang nantinya akan kerap dilakukan pada materi-materi pembelajaran tertentu untuk membuat siswa lebih mandiri dan inovatif lagi.

\section{KESIMPULAN}

Berdasrkan hasil penelitian yang telah dilakukan, maka dapat disimpulkan sebagai berikut:

1. Hasil observasi aktifitas siswa dari pertemuan pertama sampai ketiga, terlihat sangat antusias dan aktif dalam mengikuti proses pembelajaran. Nilai rata-rata aktifitas siswa pada pertemuan pertama adalah 2,967, dan pada pertemuan kedua adalah 3,562, dan pada pertemuan ketiga adalah 3,931.

2. Ketuntasan belajar dalam upaya melatih kemandirian belajar siswa melalui outdoor learning memperoleh nilai KKM pada yang diharapkan. Hal ini dikarenakan siswa lebih mudah memahami materi dan mampu menguasai konsep materi pembelajaran yang diajarkan.

3. Aktifitas siswa dan guru dalam proses pembelajaran dengan menerapkan outdoor learning sebagai upaya melatih kemandirian belajar siswa terlihat bahwa pelaksanaan outdoor learning ini sangat bermanfaat bagi guru dan siswa guna meningkatkan kualitas pembelajaran dan untuk melakukan perubahan dalam proses pembelajaran. 
R osidah U mami 0 ctavia

U paya Melatih Kemandirian Belajar M elalui Lear ning (ODL) Siswa Kelas III SDN Pucang 4 Siddoarjo

\section{DAFTAR PUSTAKA}

Arikunto, Suharsimi. 2010. Prosedur Penelitian Suatu Pendekatan Praktik. Jakarta: Rineka Cipta.

Krisnawan. 2010. Penerapan Metode Lesson Study Dalam Pembentukan Pendidikan yang Berkarakter. KTI. FKIP. Surakarma Universitas Sebelas Maret.

Lipton, Moh. 2005. Menumbuh Kembangkan Kemandirian Belajar Siswa. Yogyakarta: PT. Indeks.

Moleong, Lexy J. 2007. Metodelogi Penelitian Kualitatif. Bandung: PT. remaja Rosdakarya.

Mudjiman, Haris. 2008. Belajar Mandiri. Surakarta: UNS Press

Munandar, Utami. 2005. Mengembangkan Bakat dan Kreatifitas Anak Sekolah. Jakarta: PT Gramedia Widiasarana.

Rusman. 2011. Model-model pembelajaran mengembangkan propesionalisme guru. Jakarta: PT Raja Grafindo Persada.

Soemanto Wasty.2003. Psikologi Pendidikan. Jakarta: PT Rineka Cipta.

Sudjana. 2005. Metode Statistik. Bandung: Tarsinto.

Sugiyono. 2012. Metode Penelitian. Bandung: CV Alfabeta. 